Revista Iberoamericana. Vol. LXVI, Núm. 193, Octubre-Diciembre 2000, 737-751

\title{
ALTHUSSER, LOS ESTUDIOS CULTURALES Y EL CONCEPTO DE IDEOLOGÍA
}

\author{
POR \\ Santiago Castro-GómeZ \\ Instituto Pensar - Universidad Javeriana
}

Desde hace meses, cuando algunas personas se enteran de que estoy leyendo de nuevo a Louis Althusser y de que me gusta lo que leo, he venido escuchando comentarios que oscilan entre la perplejidad y el desasosiego. ¿Althusser? —Sauve qui peut!, ¡sálvese quien pueda! - Pocos filósofos han tenido el "honor" de ganar tantos enemigos con su obra como Louis Althusser. Los casos pueden contarse con los dedos de una mano: Maquiavelo, Spinoza, Marx, es decir, aquellos justamente a quienes el mismo Althusser recurrió una y otra vez durante su carrera. ¿Para qué leer a un autor identificado con la mácula de un pasado político que muchos quisieran no tener que recordar? ¿Qué tiene que decirnos hoy día un filósofo hipersensible, admirador de Lenin, militante incondicional del partido comunista, homosexual, que buscaba ansiosamente una entrevista con el Papa y que terminó estrangulando a su mujer en un ataque de locura? ¿No tendrá, más bien, algo de necrofílico este interés por resucitar a un "perro muerto", sobre todo cuando este perro tiene un inconfundible color rojo?

Ciertamente no son sus concesiones teóricas a la ortodoxia del partido, ni su convencimiento en la cientificidad del marxismo, ni tampoco sus repetidas y paradójicas “autocríticas” lo que me interesa rescatar de Althusser. Más interesante resulta examinar su figura en el contexto de las relaciones Nietzsche-Freud-Marx durante los años cincuenta y sesenta en Francia, con el objeto de profundizar en su crítica al humanismo y a las ciencias humanas. Pero éste no será el tema de este trabajo. Lo que quisiera resaltar aquí es la asimilación del legado de Althusser por los Estudios Culturales británicos, pero no para mirarla como una simple curiosidad histórica, sino porque estoy convencido de que ese legado puede servirnos todavía para repensar lo que significan los Estudios Culturales a comienzos de siglo en un país como Colombia.

Partiré del hecho de que mucho de lo que hoy se publica o se escribe bajo la rúbrica de "estudios culturales" parece ignorar que, en tiempos de globalización, su objeto de estudio, la cultura, se ha convertido en un bien de consumo gobernado por los imperativos del mercado. Esto quiere decir que sin una consideración seria de los vínculos entre la cultura y la economía política, los estudios culturales corren el peligro de ser estudios de nada, o mejor dicho, de perder de vista su objeto. Si los estudios culturales quieren ser, como pretenden, un paradigma innovador en el área de las ciencias sociales y las humanidades, entonces deben reconocer que la cultura se halla vinculada a un aparato de producción y 
distribución que, ya desde Marx, recibe un nombre propio: el capitalismo. Quisiera defender la tesis de que la tarea más urgente de los estudios culturales es plantear los lineamientos para una crítica de la economía política de la cultura, tarea para lo cual no se halla inerme. A su disposición se encuentra toda una tradición de pensamiento crítico elaborada durante el siglo pasado, a la cual la obra de Althusser contribuyó de manera significativa. Obviamente, esta tradición deberá ser repensada y reelaborada según las nuevas necesidades de la sociedad contemporánea.

Este trabajo estará organizado de la siguiente forma: primero examinaré la historia del proyecto de los estudios culturales británicos a partir de su relación con Althusser, tratando de encontrar la razón por la cual este proyecto empezó a perder sus vínculos con la economía política. Luego me detendré en el concepto de ideología desarrollado por el último Althusser, presentándolo como una alternativa a la noción de ideología criticada por pensadores como Foucault, Lyotard y Baudrillard. Finalmente, y de manera breve, intentaré mostrar la utilidad de este concepto de ideología para reconstruir los puentes entre los estudios culturales y la economía política, sobre todo en lo que tiene que ver con el análisis de la cultura medial.

\section{El espectro del humanismo: los estudios culturales antes y después de Althusser}

Plantear la importancia del pensamiento de Althusser para los estudios culturales no es ninguna novedad. De hecho, la historia del proyecto de los estudios culturales en Birmingham puede dividirse en dos épocas bien definidas: antes y después de su relación con Althusser.

Durante la década de los sesenta la relación de los padres fundadores de los estudios culturales con el marxismo fue ambigua, pero sirvió para establecer algunas de las líneas metodológicas que señalarían el rumbo del proyecto. Richard Hoggart, primer director del famoso Centro de Estudios Culturales Contemporáneos de la Universidad de Birmingham entre 1964 y 1968, jamás tuvo una relación directa con el marxismo. Su interés por el socialismo no venía marcado por una agenda ideológica específica, sino por la simpatía vital que, como hijo de una familia de clase trabajadora en la ciudad de Leeds, tuvo siempre por la situación de los obreros. En su libro The Uses of Literacy (1958), Hoggart describe la vida de la clase obrera en el período anterior a la segunda guerra mundial y la compara con la cultura de masas vigente en la Inglaterra de la posguerra. El tono de esta comparación es claramente nostálgico: la industria cultural ha "colonizado el mundo de la vida” de las clases populares inglesas y desarticulado su carácter orgánico. El cine, la televisión y las revistas de entretenimiento han desarraigado a los obreros de su propia cultura, exponiéndolos a la perversa influencia de la sociedad de consumo.

A diferencia de Hoggart, Raymond Williams sí estuvo influenciado por el marxismo durante sus años de formación e incluso fue miembro del Partido Comunista durante un breve tiempo. Pero su posición frente al marxismo estuvo marcada por el distanciamiento crítico. Williams opina que el marxismo trabaja con un concepto doblemente reducido de cultura: de un lado, la convierte en un reflejo distorsionado de la infraestructura económica; del otro, la limita a las manifestaciones de la cultura letrada: arte, filosofía, literatura. La “cultura” por la que Williams se interesa no es la de los productos simbólicos de las élites, 
sino la de la "experiencia vivida" por las clases trabajadoras inglesas en el seno de las grandes ciudades industriales. Williams entiende la cultura como expresión “orgánica” de formas de vida y valores compartidos que no pueden reducirse a ser epifenómeno de las relaciones económicas. Los estudios culturales deben concentrarse en el análisis de las culturas populares urbanas, descubriendo cuál es la "sensibilidad particular" que atraviesa todas sus estructuras sociales.

Edward Thompson, por su parte, también fue miembro del Partido Comunista y compartió con Williams su rechazo al determinismo económico y a toda visión “superestructuralista” de la cultura. Como Hoggart y Williams, insistió en la importancia de estudiar las formas culturales "vivas”, ancladas en la experiencia subjetiva de las clases populares inglesas, que compiten ferozmente con la cultura capitalista de masas y le oponen resistencia. Thompson se muestra partidario de un socialismo humanista, al estilo de Sartre, que pueda garantizar a las clases populares la capacidad de ser sujetos de su propia vida.

Si tomamos estas tres posiciones juntas veremos que los padres fundadores de los estudios culturales trabajaban todavía con un concepto humanista y tradicional de cultura. Utilizan el término "cultura" para referirse a la existencia de un "espíritu popular", de carácter orgánico, vinculado con la experiencia de las clases trabajadoras inglesas, y que es necesario potenciar para que ofrezca resistencia a los embates de la naciente cultura de masas. Como Horkheimer y Adorno, consideran la cultura de masas como un producto mecánico y artificial, vinculado con los intereses expansivos del capitalismo, pero, a diferencia de éstos, advierten que la industria cultural no ha logrado “cosificar” todavía por completo la consciencia de los trabajadores. Aún es tiempo de vindicar los elementos orgánicos y emancipatorios de la cultura popular, y ésta es, precisamente, la tarea política de los estudios culturales.

Sin embargo, hacia finales de los años sesenta el proyecto original de los estudios culturales empieza a experimentar un cambio de orientación política y metodológica. El movimiento estudiantil del '68 y la creciente importancia de la cultura visual en el imaginario popular hacía necesaria una revisión de los presupuestos teóricos establecidos por Hoggart, Williams y Thompson. Esta fue justamente la labor emprendida por Stuart Hall, quien asumió la dirección del Centro en 1972. Como hijo de trabajadores emigrantes jamaiquinos, Hall ya no podía mirar con nostalgia hacia el pasado de una Inglaterra impoluta frente al impacto de la “massmediatización”. Su preocupación no era "recuperar” valores culturales del pasado, sino entender el presente en sus propios términos con el fin de articular una crítica de sus patologías. Por eso, la irrupción de la sociedad de consumo y la incidencia de los medios de comunicación en el imaginario colectivo, que Hoggart, Williams y Thompson percibían todavía como amenazas contra los valores de la cultura popular, es tomada por Hall como punto de partida de los estudios culturales. Su contribución radicó en haber mostrado la necesidad de plantear un diálogo creativo con la teoría social más avanzada de su tiempo: el estructuralismo. Con Hall entramos, pues, en la etapa propiamente althuseriana de los estudios culturales.

En efecto, con la llegada de Stuart Hall a la dirección del Centro podemos hablar de un "cambio de paradigma” en la orientación de los estudios culturales: del paradigma humanista, inspirado en los estudios literarios, al paradigma estructuralista inspirado en el psicoanálisis y la teoría social marxista. Esta contraposición podríamos conceptualizarla de 
la siguiente forma: mientras que en el paradigma humanista la cultura es vista como anclada en la subjetividad de los actores sociales, en su "experiencia vivida” como decía Raymond Williams, en el paradigma estructuralista la cultura es un producto anclado en "aparatos" institucionales y que posee, por tanto, una materialidad específica. El punto de arranque de los estudios culturales ya no son los valores, las expectativas y los comportamientos de los obreros o de cualquier sujeto social en particular, sino los dispositivos a partir de los cuales los “bienes simbólicos” (la cultura) son producidos y ofrecidos al público como mercancía. El análisis de la cultura se convierte de este modo en una crítica del capitalismo.

Ahora bien, no cabe duda que en este cambio de paradigma, la influencia teórica más relevante fue la del filósofo francés Louis Althusser. El interés de Hall por Althusser se debió sobre todo a su forma de abordar el problema de la ideología. De hecho, "ideología" se convirtió en la categoría analítica más importante de los estudios culturales en los años setenta, lo cual permitió a Hall y sus colaboradores entender la cultura como un dispositivo que promueve la dominación o la resistencia. Los estudios culturales empiezan a ver la sociedad como una red de antagonismos en la que instituciones como el Estado, la familia, la escuela y los medios de comunicación juegan como mecanismos de control disciplinario sobre los individuos. Los productos simbólicos son entonces un “campo de batalla” en el que diferentes grupos sociales disputan la hegemonía sobre los significados.

Sin embargo, con la popularización de los estudios culturales en los Estados Unidos durante la década de los ochenta podemos hablar del fin de la "edad heroica” y el comienzo de una tercera etapa, más light y celebratoria, marcada por su creciente distanciamiento de la teoría crítica marxista. Me aventuraría a decir que la gran aceptación curricular que han tenido los estudios culturales en universidades norteamericanas de élite, así como su correspondiente éxito editorial, corren paralelos a este proceso de "limpieza" de sus elementos marxistas. Esta tercera etapa (post-althusseriana) está marcada por la influencia que empiezan a tener filósofos como Baudrillard, Lyotard y Derrida y, muy a pesar de estos autores, por un retorno insospechado del humanismo metodológico.

En efecto, la influencia que tuvieron algunas corrientes de la filosofía posmoderna en los estudios culturales contribuyó a marginalizar el concepto de ideología y, concomitantemente, a posibilitar el divorcio que hoy se observa entre los estudios culturales y la economía política. Lyotard, por ejemplo, desconfía de todas las teorías que, como el marxismo, pretenden disponer de un criterio de verdad que les permita saber cuáles son las contradicciones de la sociedad y cómo resolverlas. En este contexto, la crítica de las ideologías pertenecería al orden de los metarrelatos y compartiría con ellos su carácter totalitario. En vista de la complejidad de las sociedades contemporáneas, ya no resulta posible hablar de un criterio único de verdad que sirva para todos los jugadores, sino de una multitud de juegos de lenguaje que definen inmanentemente sus propias reglas y que, en muchos casos, resultan inconmensurables. Sólo a través del ejercicio de un poder autoritario sería posible decretar, como lo hace Althusser, qué es ciencia y qué es ideología. Para Lyotard, la ciencia es tan solo un juego más en la multiplicidad de juegos de lenguaje, o, dicho de otra manera, una “ideología” tan válida como cualquier otra.

Baudrillard, por su parte, argumenta que la sociedad de consumo marca el paso hacia una nueva fase del capitalismo, en la que el valor signo - y ya no el valor de cambio y mucho menos el valor de uso - regula la producción de mercancías. En este sentido, la crítica 
marxista de la ideología pierde toda su fuerza explicativa de lo social, puesto que ya no existe ninguna realidad última que develar. La sociedad entera se ha convertido en un simulacro escenificado por los media; en un intercambio regulado de signos donde no resulta posible distinguir la ficción de la realidad. Si toda la realidad social es un sistema de signos, entonces no es posible ya “salir” de la ideología a través de la ciencia, como planteaba Althusser. La ciencia ya no conoce realidades, sino interpretaciones mediadas por los códigos vigentes en la sociedad. La ciencia misma es para Baudrillard un simulacro, como también lo son todos los sistemas de creencias que usualmente denominamos "ideología”. Así las cosas, la ideología, entendida como simulacro, es un a priori de la vida en la sociedad contemporánea y, como tal, resulta irrebasable.

La celebración posmoderna de la diferencia y el rechazo de los metarrelatos totalizantes provocaron de este modo un resecamiento de la noción de ideología en el ámbito de los estudios culturales. La consecuencia más inmediata de esto es que la cultura deja de ser vista como un espacio de lucha por el control de los significados para ser considerada como “objeto” de estudio, casi de una forma positivista. La vinculación que Hall había establecido entre cultura y economía política empieza a desvanecerse y los estudios culturales se convierten en un ejercicio teórico y apolítico: en estudios sobre la cultura. Podríamos hablar, en este sentido, de un populismo cultural que celebra los supuestos efectos “democratizadores” de la sociedad de consumo. En esta nueva orientación culturalista y acrítica quisiera destacar las siguientes características:

a) Los estudios culturales pretenden convertirse en una ciencia social rigurosa, tal como la entendían Weber y Durkheim. El analista cultural, como el científico social, deben poner entre paréntesis sus valoraciones personales y describir el objeto de estudio - la cultura - tal como "es". En una palabra: los estudios culturales deben ser moralmente neutros. Utilizando la terminología de Horkheimer diríamos: los estudios culturales dejan de ser “teoría crítica” para convertirse en “teoría tradicional” de la cultura (Castro-Gómez, "Teoría”).

b) La industria cultural es vista como una función necesaria e indispensable en el seno de una sociedad compleja, sometida a procesos intensos de racionalización. Los productos de la industria cultural son una especie de sustitutos de la religión y los mitos, que satisfacen “necesidades básicas” de la población. Por esta razón, el analista cultural no debería dejarse guiar por sus preferencias personales en materia de música rock, “enlatados” o telenovelas, por ejemplo, sino que debe contemplar todos los productos simbólicos como igualmente válidos y funcionales.

c) La cultura visual es vista como fuente de “entretenimiento”, que libera a la gente del inevitable stress que representa el trabajo en una sociedad compleja. El analista debe entonces contemplar el consumo cultural como algo perteneciente a la "esfera privada" de los actores sociales.

d) Desde el punto de vista del análisis cultural, entendido como ciencia social rigurosa, no existen criterios para evaluar cuáles productos culturales son buenos o malos, mejores o peores, ideológicos o emancipadores. El único criterio evaluativo es la maximización de la funcionalidad. Por eso las industrias culturales no deben ser miradas teniendo en cuenta sus “códigos ocultos”, como pretende la crítica de la ideología, sino tan solo examinando la calidad de su gestión. Lo que importa es mirar las dinámicas internas de producción, 
presentación y distribución de los bienes simbólicos, con el fin de aumentar su eficiencia y competitividad en el mercado.

Por supuesto, no estoy diciendo que todos los practicantes de los estudios culturales en los Estados Unidos han tomado este rumbo. Basta recordar nombres como Jameson, Spivak, Ahmad, Zizek, Kellner, Mignolo y otros muchos para probar lo contrario. Lo que quiero decir es que el abandono de la categoría de ideología por parte de algunos teóricos de la cultura ha contribuido a debilitar el potencial crítico y político que tenían los estudios culturales en lo que aquí he denominado su "edad heroica”. Mucho de lo que hoy se produce y se publica en los Estados Unidos bajo la rúbrica de “estudios culturales” posee un carácter facilista y acrítico, destinado, como las hamburguesas y los perros calientes, al consumo rápido de "administradores culturales" o de estudiantes que deben absolver materias obligatorias en sus currículos de lenguas. Incluso en Colombia, los estudios culturales tienden a confundirse en algunos sectores académicos con el problema de la "gestión cultural” o con su vinculación a las "políticas culturales” del Estado.

En vista de todo lo anterior nos enfrentamos entonces a dos cuestiones: ¿Por qué se hace necesario reintroducir en los estudios culturales los vínculos con la economía política? Y, en caso de mostrarse tal necesidad, ¿cómo hacerlo? Para responder a la primera pregunta, quisiera partir del siguiente diagnóstico: en tiempos del capitalismo tardío, la “cultura” es decir, el mercado de bienes simbólicos - se ha convertido en la columna fundamental para la reproducción del capital. Esto significa que el trabajo reviste ahora la forma en que individuos o grupos generan información capaz de movilizar a otros individuos o grupos. La producción, transformación y circulación de información son el objeto de la mayor parte de las tecnologías importantes que se introducen en la economía. Dicho en otras palabras: la creación de riqueza ya no se basa tanto en la explotación de recursos naturales ni en la producción de bienes industriales de consumo, como pensaba Marx, cuanto en la producción de bienes simbólicos llevados al mercado en forma de imágenes y “conocimientos”.

Este diagnóstico tiene varias implicaciones para los estudios culturales. La más importante de ellas es, quizás, la imposibilidad de desvincular el análisis cultural de la crítica de la economía política, pero ya no en la forma "clásica” mostrada por Marx. Si el capitalismo tardío está convirtiendo al mundo en una "villa global” basada en la producción de bienes simbólicos, las premisas del trabajo industrial, la lucha de clases y el carácter superestructural de la cultura ya no pueden seguir funcionando como elementos inamovibles de la teoría crítica. Que la cultura se haya convertido en fuerza productiva significa que la nueva formación global ya no obedece a lo que Marx creía que eran las leyes del capitalismo clásico, esto es, la primacía de la producción industrial y la omnipresencia de la lucha de clases. Hoy en día, es imposible elaborar una teoría de la dominación si se toma en cuenta sólo el punto de vista de la actividad laboral en las fábricas o del sujeto que actúa sobre la materia prima para producir objetos industriales. Los estudios culturales deberían ser capaces de mostrar que la cultura, mirada todavía por Marx como un “efecto de superficie”, se halla imbricada en prácticas materiales que tienen como característica primaria la consolidación del dominio de unos grupos sobre otros. 


\section{Althusser contraataca o el CARÁcter agonístico de las ideOlogías}

En esta sección procuraré responder el segundo interrogante formulado más arriba: en caso de mostrarse la necesidad de vincular los estudios culturales con la crítica de la economía política, ¿cómo hacerlo? Mi tesis es que tal vinculación debe pasar, a nivel conceptual, por una recuperación de la categoría de ideología, pero ya no en la forma en que Marx hizo uso de ella en el siglo xix. Considero que la teoría de las ideologías desarrollada por Althusser hacia el final de su vida podría darnos algunas luces al respecto. A continuación examinaré brevemente el modo en que Althusser desarrolla una noción de ideología que escapa a las críticas de Foucault, Lyotard y Baudrillard.

En opinión de Althusser, ni Marx, ni Engels ni Lenin elaboraron jamás una teoría general de la ideología, sino que se limitaron a esbozar fragmentariamente unos principios teóricos que es necesario sistematizar y desarrollar ("Práctica teórica” 42). Marx definió la ideología como un "sistema de representaciones” que acompaña y legitima el dominio político de una clase social sobre otras. Pero Althusser piensa que se hace necesario completar la obra iniciada por Marx a través de una agenda de trabajo que incluye dos puntos: en primer lugar, se hace necesario examinar la función estructural de ese sistema de representaciones en el conjunto de la sociedad; y en segundo lugar, se debe estudiar la relación de las ideologías con el conocimiento.

Althusser afirma que toda formación social puede ser analíticamente dividida en tres niveles articulados orgánicamente entre sí: el nivel económico, el político y el ideológico. Cada uno de estos niveles es visto como una estructura dotada de materialidad concreta, independiente de la subjetividad de los individuos que participan en ella y de sus configuraciones históricas. Estos tres niveles de los que habla Althusser no son "reales" porque su estatuto no es ontológico sino teórico; tienen el carácter de "construcciones teóricas” que sirven para conceptualizar, a nivel abstracto, los diferentes tipos de relación que entablan los individuos en todas las sociedades históricas. Así, mientras en el nivel económico los individuos son parte de una estructura que les coloca en relaciones de producción, en el nivel político participan de una estructura que los pone en relaciones de clase. En el nivel ideológico, en cambio, los individuos entablan una relación simbólica en la medida en que participan, voluntaria o involuntariamente, de un conjunto de representaciones sobre el mundo, la naturaleza y el orden social ("Práctica teórica” 49). El nivel ideológico establece así una relación hermenéutica entre los individuos, en tanto que las representaciones a las que estos se adhieren sirven para otorgar sentido a todas sus prácticas económicas, políticas y sociales.

Las ideologías cumplen entonces la función de ser "concepciones del mundo" (Weltanschauungen) que penetran en la vida práctica de los hombres y son capaces de animar e inspirar su praxis social. Desde este punto de vista, las ideologías suministran a los hombres un horizonte simbólico para comprender el mundo y una regla de conducta moral para guiar sus prácticas. A través de ellas, los hombres toman conciencia de sus conflictos vitales y luchan por resolverlos. Lo que caracteriza a las ideologías, atendiendo a su función práctica, es que son estructuras asimiladas de una manera inconsciente por los hombres y reproducidas constantemente en la praxis cotidiana. Se puede decir entonces que las ideologías no tienen una función cognoscitiva (como la ciencia) sino una función práctico- 
social, y en este sentido son irremplazables. "Las sociedades humanas”—escribe Althusser"secretan la ideología como el elemento y la atmósfera indispensable a su respiración, a su vida histórica” (La revolución 192). ${ }^{1}$

En este punto se plantea el problema de la relación que guarda la teoría de las ideologías desarrollada por Althusser con la noción de ideología presente en los escritos de Marx. Como se sabe, el concepto de ideología posee en Marx un sentido fundamentalmente peyorativo. La ideología es equiparada por Marx con la "falsa conciencia”, es decir, con la imagen distorsionada que un grupo social en particular se hace de la realidad en un momento histórico determinado. Polemizando con la filosofía clásica alemana, Marx afirma que su deformación radica en tomar los contenidos de conciencia como si se tratara de entidades autónomas, punto de partida y fin último de la realidad. La "ideología alemana” — y en particular la filosofía de Hegel-genera una visión invertida del mundo: confunde las ideas con los hechos sociales, sin encontrar la esencia de los mismos. Las ideologías son, entonces, fantasmas cerebrales, ilusiones epocales, visiones quiméricas del mundo que ocultan a la conciencia de los hombres la causa verdadera de su miseria terrenal (Marx 4143). En Marx tendríamos entonces una teoría de la deformación ideológica, mas no una teoría general de las ideologías, que es la que se propone desarrollar Althusser.

En efecto, Althusser elabora una teoría general —es decir "ampliada”- de las ideologías en donde estas no aparecen simplemente como deformadoras sino como posibilitadoras de sentido. Ciertamente las ideologías se definen por su capacidad de asegurar la ligazón de los hombres entre sí (el “lazo social”), pero la función de este lazo es mantener a los individuos "fijados" en los roles sociales que el sistema ha definido previamente para ellos. Lo cual significa que las ideologías son mecanismos legitimadores de la dominación y que por tanto no pueden, a partir de sí mismas, generar ningún tipo de verdad. Pero esto no quiere decir que el papel de la ciencia sea reemplazar a la ideología, como pretendía el marxismo ortodoxo. No se trata de que algo "falso" (la ideología) sea sustituído por algo "verdadero" (la ciencia), de tal modo que el conocimiento científico se convierta en garante de la desideologización de la conciencia y de la inevitabilidad de la

\footnotetext{
${ }^{1}$ Esto significa que la ideología cumple una función social que no puede ser reemplazada por la ciencia. No es posible imaginar una sociedad en la que no existan ideologías —ni siquiera la sociedad sin clases de la que hablaba Marx - ya que sin representaciones simbólicas la vida de los hombres carecería de sentido práctico (La revolución 192). Por eso, Althusser afirma que las ideologías "no tienen historia”, lo cual no quiere decir que la historia de las ideologías acontezca por fuera de ellas, como afirmaba Marx, sino que su función social no está ligada a ninguna clase y a ninguna formación histórica en particular. Lo que cambia con el tiempo no es la ideología como tal, sino las configuraciones históricas de la ideología. Esto permite a Althusser defender la osada tesis de que la ideología, como el inconciente, es "eterna”: "Creo poder afirmar que la ideología en general no tiene historia, y esto no en un sentido negativo (su historia acontece fuera de ella) sino en uno completamente positivo. Este sentido es positivo si es verdad que lo propio de la ideología es el estar dotada de una estructura y de un funcionamiento tales que la convierten en realidad no histórica, es decir, omnihistórica en el sentido de que esta estructura y este funcionamiento están bajo una misma forma inalterable, presentes en lo que se llama la historia entera [...] Si eterno significa no lo trascendente a toda historia sino lo omnipresente, lo transhistórico y por tanto inmutable en toda la extensión de la historia, tomo entonces palabra por palabra la expresión de Freud y escribo: la ideología es eterna tal como el inconciente” (“Ideología” 130-31).
} 
revolución. Para Althusser, en el terreno de la ideología la verdad y la falsedad no juegan ningún papel, puesto que su función práctica no es generar verdades, sino "efectos de verdad”. Las “ilusiones” y las “quimeras” que según Marx produce la ideología no pueden ser "falsificadas" por la ciencia, sencillamente porque la ideología no es asimilable al "error" ni al “engaño”. En la ideología, los hombres no expresan su relación real con el mundo, sino la voluntad de relacionarse con el mundo de una manera determinada. Las ideologías son, en última instancia, voluntad de poder. ${ }^{2}$

En contra de la visión según la cual, las ideologías son fenómenos de conciencia (falsa o verdadera), Althusser afirma que se trata de una estructura inconsciente. Las imágenes, los conceptos y las representaciones que se imponen a los hombres conforman un "sistema de creencias" que no pasa necesariamente por la conciencia. Los hombres no "conocen” su ideología sino que la “viven”. Ésta, por decirlo así, permanece siempre a sus espaldas (como la Lebenswelt de Husserl) y se constituye en la condición de posibilidad de toda acción práctica. Las ideologías son “objetos culturales” que actúan realmente sobre los hombres mediante un proceso que se les escapa (La revolución 193).

En efecto, las ideologías son capaces de dotar a los hombres de normas, principios y formas de conducta, pero no de conocimientos sobre la realidad. La ideología no nos dice qué son las cosas sino cómo posicionarnos frente a ellas y, desde este punto de vista, no proporciona “conocimientos” sino únicamente "saberes”. Ahora bien, lo que caracteriza a un "saber” es que plantea problemas cuya solución se encuentra producida por instancias exteriores a él mismo. La respuesta a sus preguntas viene ya codificada de antemano por intereses de tipo moral, religioso, político o económico. Así las cosas, un saber no produce conocimientos sobre el mundo sino tan solo "efectos de conocimiento" (Para leer 74).

Sintetizando lo dicho podríamos afirmar que para el último Althusser, las ideologías no son el espacio donde se establece el juego del error y la verdad, sino el terreno de la lucha por el control de los significados. Si tomamos en cuenta esto, veremos que la teoría de las ideologías desarrollada por Althusser no es afectada directamente por las críticas de Lyotard, Foucault y Baudrillard. Lo que estos filósofos critican es la tesis de la deformación de la conciencia, mientras que, como queda dicho, Althusser no utiliza una noción “negativa” sino "agonística” de ideología. Quisiera enfatizar la diferencia entre estos dos términos.

El concepto de ideología, entendido en sentido negativo, presupone una "realidad real" que imprime indefectiblemente su sello en la conciencia. Si entre el individuo y la realidad no mediaran las relaciones sociales, lo único que habría que hacer sería "mirar" al mundo para descubrir su verdad intrínseca. Pero como nuestra mirada se encuentra perturbada por intereses de clase, la verdad del mundo social queda muchas veces oculta a la conciencia. En esta situación, se hace necesario recurrir a un conocimiento especializado - la cienciaque sea capaz de separar la verdad y el error, para mostrarnos aquello que no podemos ver

\footnotetext{
${ }^{2}$ Paul Ricoeur señala que en la teoría althusseriana de las ideologías existe un fuerte componente nietzscheano. La ideología es irremplazable porque los hombres necesitan dar algún sentido a sus vidas y este sentido no lo puede proporcionar la ciencia. En otras palabras: necesitamos ilusiones que nos permitan soportar la dureza de la vida. Las ideologías cumplen entonces una importante función vital, pues son intentos de dar sentido a los accidentes de la vida y a los aspectos más penosos de la existencia humana. Las ideologías son ilusiones necesarias para la supervivencia (Ricoeur 56).
} 
por causa de nuestra inmersión en las contradicciones sociales. El cientista social juega entonces la función del hermeneuta: parte de un texto superficial que considera "sintomático" de una realidad más profunda, que se revela como su verdad última. Este es el modelo de crítica de la ideología desarrollado por Marx y por el mismo Althusser durante los años cincuenta y sesenta.

Pero en los setenta Althusser se aparta de esta noción "negativa” y de este modelo de “crítica” para adoptar lo que hemos llamado una noción "agonística” de ideología. Aquí las ideologías son vistas como un "sistema de creencias" que no tienen necesariamente una adscripción de clase y que sirven para imputar “sentido” al mundo y a nuestra praxis en el mundo. Nótese que en este caso las ideologías no son síntomas de una verdad más profunda, puesto que aquello que los actores sociales tienen por "verdadero" es un asunto de simple y llana imputación o voluntad de verdad. Este desplazamiento teórico tiene por lo menos cuatro consecuencias importantes, que describiré brevemente:

a) Se rompe con la visión de Marx según la cual, las ideas dominantes expresan posiciones fijas de clase al interior de la estructura social. Lo que se destaca ahora es el hecho de que una ideología no se hace dominante por el simple hecho de "reflejar" los intereses de una clase, sino que su ascendencia es un proceso contingente de lucha por el poder de imputar sentido. ${ }^{3}$ En otras palabras, y como también lo diría Gramsci, para Althusser la ideología es el campo de lucha por la conquista de la hegemonía en el terreno de las representaciones simbólicas — es decir, de la cultura.

b) No se puede establecer una contraposición entre la ciencia y la ideología puesto que, en sí misma, la ciencia es una estructura discursiva que procede mediante la imputación de sentido. Es decir que el problema de la "verdad científica” se define, en últimas, en el terreno de las políticas del conocimiento. Qué tipo de sentido se imputa a la realidad no es algo que dependa exclusivamente de criterios intracientíficos, sino que en ello intervienen criterios de orden moral, económico y político. También la ciencia, en tanto que socialmente preformada, se encuentra preñada de ideología y es objeto de la lucha por la hegemonía.

c) La crítica de la ideología no utiliza el código binario verdad-error, puesto que una visión del mundo sólo puede ser interpelada desde otra visión del mundo. Es decir que la crítica se hace siempre desde un "sistema de creencias" diferente, que no es más o menos verdadero que el que se critica, sino más o menos fuerte. La fortaleza o la debilidad de este sistema de creencias viene dada por la conquista de posiciones de poder en el terreno de la política.

d) El intelectual deja de ser visto como el "experto" que, en virtud de la autoridad de su saber, posee algo que el pueblo llano jamás ha poseído: la llave del acceso a la verdad. El problema no es que las masas se encuentren desposeídas de conocimientos que les permitan interpretar su propia praxis, sino que han sido determinadas políticas de la verdad las encargadas de deslegitimar ese conocimiento y de investir a los "expertos” con la prerrogativa de ser los únicos intérpretes autorizados de la verdad social.

\footnotetext{
${ }^{3}$ Esto significa, a su vez, que la "unidad" de un grupo de personas no es construida por su pertenencia a un "modo de producción”, como pensaba Marx, sino al modo particular en que asumen una ideología.
} 
Si tuviéramos que sintetizar estos cuatro puntos en una sola fórmula que vincule lo dicho con el problema de los estudios culturales, diríamos lo siguiente: aquello que “estudian” los estudios culturales no es algo que se encuentre por fuera de la ideología, ni tampoco algo que pueda ser visto desde una posición desideologizada. Los estudios culturales expresan, por el contrario, una voluntad de intervención activa en la lucha contra las prácticas sociales de dominación y subordinación, haciendo énfasis en el modo particular en que estas prácticas se manifiestan en el terreno de las representaciones simbólicas. Con Jameson podríamos decir, entonces, que los estudios culturales no pueden ser otra cosa sino partidistas, porque toda posición frente a la cultura es, necesariamente, una toma de posición política frente a la naturaleza y los efectos del capitalismo transnacional actual.

\section{LA GUERRA DE LAS IMÁGENES: HEGEMONÍA AUDIOVISUAL Y APARATOS IDEOLÓGICOS}

En los dos apartados anteriores he defendido la tesis de que, en tiempos de globalización, los estudios culturales se enfrentan al desafío de retomar sus vínculos con la economía política. He procurado mostrar que para asumir este desafío, los estudios culturales deberían elaborar un concepto de ideología lo suficientemente amplio como para servir de instrumento crítico de la dominación, pero que les permita, al mismo tiempo, escapar a las críticas realizadas por pensadores como Foucault, Lyotard y Baudrillard. Apelando a los últimos textos de Louis Althusser he querido descubrir allí una noción “agonística” de ideología que, a mi juicio, podría servir para cumplir esta tarea. En esta última sección mi argumento estará dirigido hacia el modo en que este concepto agonístico podría resultar útil para una lectura de los mensajes simbólicos que circulan por los medios.

Quisiera comenzar de nuevo con Althusser, haciendo referencia a su famosa teoría de los aparatos ideológicos. Al igual que Marx, Althusser piensa que las “ideas” y las "representaciones" mentales no tienen existencia espiritual sino material, en tanto que se encuentran ancladas en instituciones específicas que él denomina "aparatos”. Un aparato es una estructura que funciona con independencia de la "conciencia" de los individuos vinculados a ella, y que puede configurar la subjetividad de esos individuos. ${ }^{4}$ Althusser utiliza la palabra francesa dispositif para enfatizar el hecho de que las motivaciones ideológicas de los individuos se encuentran siempre ligadas a un conjunto anónimo de “reglas” materiales (“Ideología” 135, 137).

Este carácter simbiótico entre las normas materiales de un aparato y las motivaciones ideológicas de los sujetos es, precisamente, el que explica por qué razón los aparatos ideológicos no poseen un carácter represivo. Althusser establece una diferencia clara entre los aparatos represivos y los no represivos, mostrando que los primeros crean perfiles de subjetividad a través de la coacción, mientras que los segundos no necesitan de la violencia coactiva. Aquí, los individuos han internalizado de tal manera las reglas anónimas del aparato, que ya no experimentan su sujeción a ellas como una intromisión en su vida privada.

${ }^{4}$ Como bien lo anota Paul Ricoeur en sus comentarios al concepto de ideología en Althusser: "For Althusser the concept of action is too anthropological; practice is the more objective term. Finally, it is only the material existence of an ideological apparatus which makes sense of practice. The apparatus is a material framework, within which people do some specific things” (Ricoeur 63). 
En su texto "Ideología y aparatos ideológicos del Estado” (116) Althusser menciona ocho tipos de instituciones que, a diferencia de los aparatos represivos, no "sujeta” a los individuos a través de prácticas violentas sino a través de prácticas ideológicas:

- Aparatos religiosos (iglesias, instituciones religiosas)

- Aparatos educativos (escuelas, universidades)

- Aparatos familiares (el matrimonio, la sociedad familiar)

- Aparatos jurídicos (el derecho)

- Aparatos políticos (partidos e ideologías políticas)

- Aparatos sindicales (asociaciones de obreros y trabajadores)

- Aparatos de información (prensa, radio, cine, televisión)

- Aparatos culturales (literatura, bellas artes, deportes, etc.)

Nos interesa en este momento analizar aquello que Althusser denomina los “aparatos de información” porque, como ya se dijo, en el capitalismo tardío la cultura medial se ha convertido en el lugar de las batallas ideológicas por el control de los imaginarios sociales. Por su radio de alcance y por su formato visual, los medios contribuyen en gran manera a delinear nuevas formas de subjetividad, estilo, visión del mundo y comportamiento. La cultura medial es el aparato ideológico dominante hoy en día, reemplazando a la cultura letrada en su capacidad para servir de árbitro del gusto, los valores y el pensamiento. La ventaja de la cultura medial sobre los otros aparatos ideológicos radica, precisamente, en que sus dispositivos de sujección son mucho menos coercitivos. Diríamos que por ellos no circula un poder que "vigila y castiga", sino un poder que seduce. No estamos, por tanto, frente al poder disciplinario de la modernidad, criticado por Foucault, sino frente al poder libidinal de la globalización. ${ }^{5}$

Aplicando lo dicho en el apartado anterior al tema de la cultura medial podríamos decir que, en tiempos de globalización, los medios son el terreno para el establecimiento del dominio de unos grupos sobre otros, pero también son, al mismo tiempo, el terreno apropiado para la resistencia contra ese dominio. En una palabra, los medios son el lugar de lucha por la hegemonía cultural. Siendo los medios la principal fuente generadora de ideologías en la sociedad contemporánea, su control se constituye en una clave fundamental para la consolidación del dominio político. Los medios producen y fortalecen "sistemas de creencias" a partir de los cuales unas cosas son visibles y otras no, unos comportamientos son inducidos y otros evitados, unas cosas son tenidas por naturales y verdaderas, mientras que otras son reputadas de artificiales y mentirosas.

La pregunta que quisiera formular en este punto es la siguiente: ¿de qué modo puede hacerse valer el concepto agonístico de ideología para reconstruir el puente entre los estudios culturales y la economía política, atendiendo al caso específico del análisis de los medios? Estoy convencido de que una ampliación del concepto de ideología, tal como ha sido sugerida por Althusser, podría resultar muy valiosa para entender cómo las imágenes, figuras y narrativas simbólicas que circulan por la televisión construyen representaciones que sirven para reforzar el dominio de unos grupos sobre otros. Estas representaciones

\footnotetext{
${ }^{5}$ Este argumento lo he desarrollado con amplitud en otro lugar (Castro-Gómez, “Teoría tradicional
} y teoría crítica de la cultura”). 
ideológicas no son, por supuesto, unitarias, como pensaba el primer Althusser. A través de los medios se construyen no solo las grandes ideologías económicas y políticas, sino también ideologías de género, raza, sexualidad y posición social que no son necesariamente reducibles unas a otras. Con todo, si hay algo que estructuralmente las unifica es su vinculación al aparato de producción y, por tanto, el modo en que tales representaciones ideológicas se inscriben en la competencia de unos medios con otros por "seducir" a los consumidores.

Tomemos como ejemplo el modo en que los medios han servido como escenarios para la construcción ideológica de problemas tales como la corrupción y la guerra. El proceso $8000^{6}$ reveló una polarización ideológica de los medios jamás vista en Colombia. Allí se mostró de forma clara que la lógica del mercado — que en tiempos de globalización podría traducirse como la "lógica de la imagen" — no se encuentra regida por una mano invisible, sino por voluntades encontradas que luchan por escenificar su propia visión del mundo. Los noticieros de televisión en Colombia no son mentes abstractas que, como el cogito de Descartes, sirven para trasmitir a los televidentes ideas “claras y distintas”, sino que sus pertenencias terrenales resultan evidentes. Los dueños de las programadoras más grandes del país no son ni siquiera individuos particulares — pues nadie, ni siquiera Pablo Escobar, tendría el poder para escenificar sus intereses de este modo ${ }^{7}$ — sino monopolios económicos locales, que a su vez se vinculan con otros monopolios de carácter global. Bastaba cambiar el canal para darse cuenta de que la versión sobre un mismo evento cambiaba según el noticiero que informaba. Y este “cambio” puede explicarse aplicando la noción de ideología arriba esbozada. Lo que se estaba escenificando en el proceso 8000 era una encarnizada lucha ideológica por parte de los grupos económicos, que vieron amenazada su hegemonía cuando el incidente de los dineros calientes salió de su control.

Me parece, por tanto, equivocado interpretar el proceso 8000 como si los medios estuviesen denunciando una corrupción que se encontraba por fuera de ellos, en el espacio ilustrado de la política o de los partidos políticos. Insistamos en que la globalización ha cambiado el lugar de la economía política, desplazándola hacia el reino de la imagen y los símbolos. Por ello, la llamada "corrupción de la política” no era algo que estuviese ocurriendo más allá o más acá del espacio de los medios, sino que los medios mismos estaban generando unas políticas de la representación respecto al sentido que había que

\footnotetext{
${ }^{6}$ El “proceso 8000” hace referencia a la investigación adelantada por la Fiscalía General de la Nación en contra del presidente de Colombia, Ernesto Samper Pizano, y mediante la cual se le acusó de haber recibido dinero proveniente del narcotráfico — concretamente del Cartel de Cali- para financiar su campaña presidencial. El escándalo se desató a partir de la entrega a la Fiscalía de unas grabaciones (los famosos "narcocassettes") por parte del derrotado candidato presidencial (y ahora presidente) Andrés Pastrana, en las cuales se registraban testimonios que comprometían gravemente la campaña de Samper. Este negó siempre haber estado enterado del ingreso de tales dineros. Pero la Fiscalía comprobó que los dineros llegaron — con o sin el conocimiento y aprobación del electo presidente. A raíz de esta investigación, sin precedentes en al historia política del país, rodaron muchas cabezas, entre ellas la del entonces Ministro de Defensa, Fernando Botero, hijo del famoso pintor colombiano, quien en este momento se encuentra exiliado en Inglaterra.

${ }^{7}$ Bourdieu ha mostrado que el poder no depende sólo de la posesión de capital económico, sino también del acceso privilegiado al capital social y cultural.
} 
imputársele a esa “corrupción”. El juego de poderes y contrapoderes se estaba jugando en los medios y no por fuera de ellos. Ampliando la reflexión diríamos que la corrupción de la que hablan los medios no es algo "en-sí”, sino que es una representación ideológica de segundo grado. Los códigos morales vigentes en una sociedad - o en un sector de ellacrean un juicio respecto de una conducta a la que denominan "corrupción” y lo convierten en naturaleza segunda, como es propio de toda ideología. Los medios, a su vez, escenifican la lucha por imputar un sentido adicional a ese juicio moral, convirtiéndolo en naturaleza ya no segunda sino tercera.

Algo parecido podría decirse respecto al manejo que los medios están dando al problema de la guerra en Colombia. La opinión generalizada es que las imágenes de los cuerpos mutilados transmitidas por los medios "hablan por sí mismas" y son, por ello, capaces de horrorizarnos. Esto es cierto solamente en parte. Que un cuerpo mutilado produzca en nosotros un sentimiento denominado "horror" y que valoremos esa visión como algo “repugnante e indigno”, es un juicio ideológico que, gracias a un largo proceso de decantación histórica, ha llegado a convertirse en naturaleza segunda. Pero de ser plausible lo dicho anteriormente, podríamos afirmar que los cuerpos mutilados que vemos por televisión no hablan por sí mismos. Ellos son obligados a hablar de uno u otro modo, según los intereses económicos y políticos de las programadoras. Todo depende del modo en que es escenificada la noticia. En una situación puramente ideal, la imagen televisiva de un cuerpo mutilado podría ser interpretada por un personaje entrevistado como un "acto terrorista”, como una "acción represiva del estado" o como una prueba de que el país necesita de "mano dura" para terminar con el conflicto. Hablo de una "situación ideal" porque, en realidad, el entrevistado es casi siempre un miembro del gobierno o un general del ejército, aunque últimamente las autodefensas están recibiendo bastante "pantalla” por parte de los medios.

Lo que quiero decir es que el significado de un cuerpo mutilado ya no se juega hoy en día en el ámbito cotidiano del "mundo de la vida", sino en el escenario "sistémico" de los medios, para utilizar las categorías desarrolladas por Habermas. Y en este ámbito sistémico, lo que cuenta no es la "acción comunicativa”, sino el modo en que una representación ideológica es producida, montada, seleccionada y presentada como "naturaleza tercera”, de acuerdo a dispositivos globales de poder. La guerra de las imágenes sobre la guerra será ganada por aquel grupo que utilice mejor el poder libidinal para imputar sentido, es decir, que ponga en marcha todos los mecanismos seductores de la imagen para lograr el consentimiento no coercitivo de los consumidores.

Teniendo en cuenta todo lo anterior, discrepo de la opinión de algunos analistas culturales, para quienes los medios de comunicación han servido para ampliar considerablemente el espacio de lo público y se convierten, por tanto, en instrumentos de la democracia. Los medios serían algo así como el ágora posmoderna, en donde es posible debatir todas las opiniones, discutir todos los intereses e interactuar con todas las posiciones ideológicas. Los medios aparecen de este modo como espacios neutros para la formación de la ciudadanía. Me parece que esto es justamente lo que ocurre cuando los estudios culturales abandonan el concepto de ideología. Entonces se muestran incapaces de tender los lazos con la economía política y de mostrar que la información es precisamente eso: informar, esto es, dar forma ideológica a una materia preexistente. Una forma ideológica que, 
como he procurado demostrar, se encuentra vinculada con imperativos estructurales de carácter global.

\section{Bibliografía}

Althusser, Louis. La revolución teórica de Marx. 2ª edición. México: Siglo xxi, 1968. Lenin y la filosofía. 2 $2^{\text {a }}$ edición. México: Serie Popular Era, 1975.

Curso de filosofía para científicos. Bogotá: Planeta, 1985.

Filosofía y marxismo. 2 2a edición. México: Siglo xxi, 1998.

“La filosofía como arma de la revolución”. La filosofía como arma de la revolución. 21 edición. México: Siglo xxı, 1997.

“Práctica teórica y lucha ideológica”. La filosofía como arma de la revolución. 21 edición. México: Siglo xxi, 1997.

“Acerca del trabajo teórico”. La filosofía como arma de la revolución. 21 edición. México: Siglo xxi, 1997.

“Ideología y aparatos ideológicos del Estado". La filosofía como arma de la revolución. 21 edición. México: Siglo xxi, 1997.

"Nota sobre el "Humanismo real”. Louis Althusser, Jorge Semprún, Michel Simon y Michel Verret. Polémica sobre marxismo y humanismo. 9a edición. México: Siglo XXI, 1980.

y Étienne Balibar. Para leer El Capital. 23 edición. México: Siglo xxı, 1998.

Bachelard, Gaston. La formación del espíritu científico. Contribución a un psicoanálisis del conocimiento objetivo. 22 edición. México: Siglo xxi, 1999.

Castro-Gómez, Santiago. “Teoría tradicional y teoría crítica de la cultura”. La reestructuración de las ciencias sociales en América Latina. Santiago Castro-Gómez, ed. Santafe de Bogotá: CEJA, 2000.

Marx, Karl y Friedrich Engels. La ideología alemana. Crítica de la novísima filosofía alemana en las personas de sus representantes Feuerbach, B. Bauer y Stirner, y del socialismo alemán en las de sus diferentes profetas. Wenceslao Roces, trad. Buenos Aires: Ediciones Pueblos Unidos, 1975.

Ricoeur, Paul. "Althusser‘s Theory of Ideology”. Althusser. A Critical Reader. Gregory Elliot, ed. Oxford: Blackwell Publishers, 1994. 